\title{
Men Are from Mars, Women Are from Venus: Gender and Mergers and Acquisitions*
}

\author{
Maurice Levi \\ Sauder School of Business \\ University of British Columbia \\ 2053 Main Mall, Vancouver, BC V6T 1Z2 \\ maurice.levi@sauder.ubc.ca \\ Kai Li \\ Sauder School of Business \\ University of British Columbia \\ 2053 Main Mall, Vancouver, BC V6T 1Z2 \\ kai.li@sauder.ubc.ca \\ Feng Zhang \\ David Eccles School of Business \\ University of Utah \\ 1645 E. Campus Center Dr., Salt Lake City, Utah 84112 \\ feng.zhang@business.utah.edu
}

This version: November, 2011

\begin{abstract}
This paper examines the influence of female directors on corporate boards on mergers and acquisitions (M\&As). Using acquisition bids initiated by S\&P 1500 firms during 1997-2009, we find that each ten-percent representation of female directors on a corporate board is associated with a reduction in the number of a company's acquisition bids by 7.5 percent: women are less acquisitive than men. Furthermore, using over 450 acquisition bids for which we have data on bidder and target firm characteristics and their board membership, we find that each ten-percent of female directors on a bidder board is associated with a reduction in the bid premium by 13.3 percent. There is no significant effect of female directors on a target board. We argue that these results are what we would expect if, as other researchers have shown, women are less overconfident than men when facing difficult tasks lacking fast, clear feedback.
\end{abstract}

Keywords: director gender, overconfidence, bid initiation, bid premium, mergers and acquisitions

JEL classification: G34, G38

\footnotetext{
* We thank Huasheng Gao, Steve McKeon, Michael Meloche, Seki Obata, seminar participants at McMaster University and Queens University, and conference participants at the Institute of Economic Research Hitotsubashi University Summer Research Workshop, the 2011 Northern Finance Association Meetings, and the 2011 Annual Meeting of the Academy of Behavioral Finance \& Economics for helpful comments. This paper is the recipient of the Best Doctoral Student Paper in Behavioral Finance Award at the 2011 Annual Meeting of the Academy of Behavioral Finance \& Economics. Levi and Li acknowledge the financial support from the Social Sciences and Humanities Research Council of Canada. We also acknowledge the financial support from the Certified Management Accounting Society of British Columbia. All remaining errors are our own.
} 


\title{
Men Are from Mars, Women Are from Venus: Gender and Mergers and Acquisitions
}

\begin{abstract}
This paper examines the influence of female directors on corporate boards on mergers and acquisitions (M\&As). Using acquisition bids initiated by S\&P 1500 firms during 1997-2009, we find that each ten-percent representation of female directors on a corporate board is associated with a reduction in the number of a company's acquisition bids by 7.5 percent: women are less acquisitive than men. Furthermore, using over 450 acquisition bids for which we have data on bidder and target firm characteristics and their board membership, we find that each ten-percent of female directors on a bidder board is associated with a reduction in the bid premium by 13.3 percent. There is no significant effect of female directors on a target board. We argue that these results are what we would expect if, as other researchers have shown, women are less overconfident than men when facing difficult tasks lacking fast, clear feedback.
\end{abstract}

Keywords: director gender, overconfidence, bid initiation, bid premium, mergers and acquisitions

JEL classification: G34, G38 
It is not necessary to visit other planets to recognize the differences between men and women living right here on Earth. Natural selection has invested in men a stronger drive for dominance than is found in women, which is hardly surprising given the different roles men and women play in procreation and the nurturing of offspring. If we were to seek a single word that would best capture the bio-evolutionary aspect of women, a good candidate would be that women are more "cautious." This has been observed in children's play, alcohol consumption, smoking, driving, sexual activity, choice of jobs, and behavior in the jobs chosen (see for example, Sax (2005), and Sapienza, Zingales, and Maestripieri (2009)).

Caution takes a specific form in one important aspect of behavior with a potential bearing on mergers and acquisitions (M\&As), namely a well-documented tendency of women to be less overconfident than their male counterparts (see the survey by Croson and Gneezy (2009)). Overconfidence is typically postulated to take one of two forms. The first concerns the precision of beliefs about future uncertain events (see for example, Barber and Odean (2001)). Specifically, evidence has been gathered and described showing that women view their predictions of how the future will unravel as being less precise than men view the precision of their own predictions. In other words, women see their predictions as belonging to a more dispersed distribution of possible outcomes. The second form of women being less overconfident concerns the level of expectations of what will happen (see for example, Malmendier and Tate $(2005,2008))$. It is shown that in the same circumstances, women see future outcomes in less favorable terms than men do: while both are overconfident, men are more so. Whichever form of overconfidence we consider, the less overconfident attitude of women results in a relative hesitation to undertake difficult tasks lacking fast, clear feedback. 
This paper investigates whether the lower overconfidence of women is manifested in female directors on corporate boards being less acquisitive than their male counterparts. This will happen if, ceteris paribus, the same acquisition is seen as more attractive to men due to their greater overconfidence about the acquisition in either or both of the ways described above. We also investigate whether the lower overconfidence of women on bidder boards results in the payment of lower bid premiums for target firms that are acquired.

M\&As are an ideal setting for investigating the implications of male versus female behavioral traits for several reasons. First, takeovers are highly significant economic activities that often do not add shareholder value (see the survey by Andrade, Mitchell, and Stafford (2001), and the recent evidence from Chen, Harford, and Li (2007)), so it is important to understand why so many deals fail. For example, could bidder male directors' overconfidence result in too many acquisitions or in paying too much? Second, according to Lenney (1977), gender differences in overconfidence depend on the lack of clear and unambiguous feedback. Specifically, when feedback is "unequivocal and immediately available, women do not make lower ability estimates than men. However, when such feedback is absent or ambiguous, women seem to have lower opinions of their abilities and often do underestimate relative to men." M\&A successes and failures are not easily or immediately identifiable due to their uniqueness, complexity, scale, and other factors that influence overall acquirer performance. It is thus expected that men will be more confident than women about their ability to make acquisitions. These arguments make M\&As an excellent platform for asking the following questions: is there any association between women representation on corporate boards and M\&A activities and terms, and is any such association consistent with women being less overconfident than men? 
Using close to 20,000 firm-year observations for the period 1997-2009, we show a negative and significant association between the fraction of female directors on a corporate board and the number of acquisition bids: women are less acquisitive than men. In terms of the economic significance, each ten-percent of female directors on a board, corresponding to approximately one female director, reduces the number of acquisition bids by 7.5 percent. Having multiple female directors leads to even fewer acquisitions. That is, the effect of female directors on corporate acquisitiveness is non-linear. Since the decision to acquire depends on the confidence of the directors, in terms of either (both) the precision of their estimate of or (and) their expected value of an acquisition, not to acquire is consistent with female directors' lower estimate of the value of an acquisition.

In addition to evidence on acquisitiveness, using data from over 450 acquisition bids for which information on the bidder and target firm characteristics and board membership are available, we find that female directors on a bidder board are negatively and significantly associated with the size of the bid premium. In terms of the economic significance, each tenpercent of female directors on a bidder board is associated with a lower bid premium of 13.3 percent. A lower bid premium is consistent with bidder female directors' relatively lower overconfidence in the precision of their estimate of and/or in their expected valuation of an acquisition.

Our goal in this paper is to report these economically and statistically significant associations between gender and M\&A deals and between gender and M\&A terms, and to indicate linkages to recent research suggesting that women exhibit less overconfidence (see for example, Lichtenstein, Fischhoff, and Phillips (1982), Beyer (1990), and Barber and Odean (2001)). It should be pointed out that our investigation shares the same endogeneity concerns as 
the majority of investigations relating to corporate boards. For example, one could argue that an entrenched CEO prefers a "quiet life" and thus chooses women board members who are generally less overconfident and thereby less acquisitive. Alternatively, maybe a particular CEO by nature is an empire-builder and thus not appealing to women board members who are less overconfident. ${ }^{1}$ In these cases, causation does not go from female directors to corporate decisions, including M\&As, but from corporate decisions to female directors. Nevertheless, in either case the outcome can be traced back to female board members being less overconfident than male board members. As such, we still have reason to examine the association between female representation on corporate boards and the frequency of M\&A deals and the price paid for target firms. Finally, concern over endogeneity is further mitigated by the robustness of the observed association after controlling for firm and director characteristics and industry effects.

The outline of the paper is as follows. The next section reviews the related literature and develops our hypotheses. Despite an absence of prior work on the role of board gender diversity in M\&As, studies of gender in other finance contexts provide the basis for the suggested associations we evaluate in this paper. Section II presents the results on the statistical and economic significance of female directors for bid initiation. Section III presents the results on the importance of female directors for bid premiums. Section IV investigates the possibility that our results are capturing effects other than those of gender differences in overconfidence. Section V summarizes and concludes.

\section{Literature Review and Hypothesis Development}

\footnotetext{
${ }^{1}$ Acquisitiveness due to CEO overconfidence differs from the conventional view of empire building (Jensen (1986, 1988)) in that CEOs may well believe they are acting in shareholders' interest and as such there may be no agency problem (see Malmendier and Tate (2008)).
} 
Our research is related to prior investigations of the effects of gender on behavior in general and in finance contexts in particular. The behavioral differences of women and men in general are non-controversial. As has been mentioned, women are distinctly more cautious than men, a matter that can be attributed to the greater investment that is made in the process of reproduction and thereby in the survival of our species (see for example, Knight (2002)). This is evidenced by safer play behaviors of girls and women's more cautious behaviors involving sex, drugs and alcohol, gambling, driving, and in employment choices (see for example, Sax (2005), and Sapienza, Zingales, and Maestripieri (2009)).

\section{I.A. Literature on Gender Differences in Finance}

In terms of the effects of gender on financial behaviors, the evidence is more equivocal, with not every investigation having identified statistically or economically significant differences in behavior between the sexes.

Using data from the 1992 and 1995 Surveys of Consumer Finances, Sundén and Surette (1998) show that both gender and marital status significantly affect how individuals choose to allocate assets under defined-contribution pension plans. Using account data for over 35,000 households from a large discount brokerage, Barber and Odean (2001) document that men trade more frequently than women, and men's increased trading reduces their net returns as compared to women's, consistent with men being more overconfident than women.

With respect to professional money managers, using data from nearly 2,000 mutual fund investors, Dwyer, Gilkeson, and List (2002) find that women take less risk than men in their mutual fund investments. However, the observed gender difference in risk taking is significantly attenuated after controlling for financial investment knowledge. Similarly, Atkinson, Baird, and 
Frye (2003) find that male and female mutual fund managers appear similar in terms of fund performance, risk, and other fund characteristics after controlling for wealth and knowledge differences between them.

Using Fortune 500 firms during the 1990s, Farrell and Hersch (2005) show that women tend to serve as directors on better performing firms, but they also document that there is no wealth effect associated with the announcement of a woman being added to the board. Using a cross-sectional sample of boards of directors of 1,024 publicly traded US firms, Adams and Ferreira (2009) show that firms facing less uncertainty (as measured by return volatility) have more women directors. They also find that boards with more women directors are associated with more director pay-performance incentives and more board meetings. Using a merged panel of directors and executives for large U.S. corporations between 1997 and 2009, Masta and Miller (2011a) find a positive association between the fraction of female directors on the board in the previous year and the fraction of female top executives in the current year. Ahern and Dittmar (2011) examine the relationship between board structure and firm value using a new law in Norway requiring that 40 percent of corporate board members be women. They find that the law led to a significant negative impact on firm value, due to new (female) board members' younger age and lack of high-level work experience. Examining the same quota system in Norway, Masta and Miller (2011b) further show that firms affected by the quotas faced increased relative labor costs and employment levels, reducing short-term profits. It is worth noting that with the exceptions of Ahern and Dittmar (2011) and Masta and Miller (2011b), research in this area, as mentioned earlier, falls short of establishing a causal relationship between gender and economic outcomes. However, Ahern and Dittmar (2011) and Masta and Miller (2011b) had a natural 
experiment from the mandatory change in the minimum representation of women on Norwegian corporate boards.

Given that boards meet infrequently, the role of the board is most likely to be detectable in large, discrete corporate decisions requiring board approval, rather than in the day-to-day operations that contribute to long-run stock and operating performance. This motivates our focus in this paper on the previously unexplored association between female representation on corporate boards and acquisition decisions.

\section{I.B. Our Hypotheses}

As mentioned in the introduction, it is well established that while people in general are overconfident, women are less overconfident than men (see the survey by Croson and Gneezy (2009), and earlier work by Lichtenstein, Fischhoff, and Phillips (1982), and Beyer (1990)). Furthermore, it has been shown that people's overconfidence is greatest for difficult tasks and for undertakings lacking fast, clear feedback (Lenney (1977), and Barber and Odean (2001)). Given the complexity and distinct characteristics associated with each deal, M\&As represent an ideal setting to examine gender differences in overconfidence that may be due to a less precise view of (Barber and Odean (2001)) and/or a less favorable view of the value of an acquisition (Malmendier and Tate (2008)). ${ }^{2}$ As a consequence of either or both channels, might we expect female directors on bidder boards to restrain support for proposed deals relative to their male counterparts, and perhaps to persuade the board to decide against making an offer? That is, does the presence of bidder female directors reduce the likelihood an acquisition is made? Also, as the

\footnotetext{
${ }^{2}$ Overconfidence has also been interpreted as an "illusion of control:" men have a stronger belief they can control what happens (see Langer (1975), and Deaves, Lüders, and Luo (2009)). Such an interpretation shares elements of the two interpretations discussed in this paper, i.e., men's perception of more precise and/or more favorable target evaluation.
} 
bidder board and shareholders are concerned with not paying too much, is there pressure to accommodate a female director's less favorable view of how much to offer? That is, are female directors associated with smaller bid premiums? As a result, we have the following null and alternative hypotheses:

\section{With respect to acquisition bids:}

$\boldsymbol{H}_{0}$ : The fraction of female directors on a board is not associated with the propensity to initiate acquisition bids.

$\boldsymbol{H}_{1}$ : The fraction of female directors on a board is associated with the propensity to initiate acquisition bids.

\section{With respect to the bid premium:}

$\mathbf{H}_{0}$ : The fraction of female directors on a bidder board is not associated with the size of the bid premium.

$\boldsymbol{H}_{1}$ : The fraction of female directors on a bidder board is associated with the size of the bid premium.

In contrast to the effects of female representation on a bidder board, we do not expect female representation on a target board to affect bid initiation given that bid initiation is most likely discussed between bidder and target CEOs after approval by the bidder board; the target firm is typically the passive responder. ${ }^{3}$ We also expect the gender composition of the target board to have a weaker effect on the bid premium than that of the bidder board for the following reasons.

First, there is an information asymmetry between bidder and target boards with respect to the value of the target firm. Both female and male directors on target boards can be expected to have better information than their counterparts on bidder boards regarding the value of their own

\footnotetext{
${ }^{3}$ Unfortunately we are in any case lacking target board information in our large bid initiation sample.
} 
firms. Hence, even though female directors may be less overconfident than male directors, the potential for a gap between the views of female and male directors on target boards about their own firm value is relatively small: directors of both genders have a more precise view of target value, narrowing room for any gender-based overconfidence differential. ${ }^{4}$ This lack of information asymmetry leads to a lack of association between female directors on target boards and the size of the bid premium. ${ }^{5}$

Second, the concern of target firm directors and shareholders is with accepting too little. Given "sell high" preferences of the target board and shareholders, there is less compelling pressure to accommodate a lower (less overconfident) valuation of the target firm by female directors who might be willing to settle for a lower price: the target board does not want to be accused of accepting too little. Hence, we expect that there should be a weaker effect of female directors on the target board than on the bidder board on the size of the bid premium.

\section{Gender Diversity and Bid Initiation}

\section{II.A. Model Specification}

To explore the role of board gender diversity in initiating M\&As, i.e., acquisitiveness, we run the following Negative Binomial regression focusing on the fraction of female directors on a board:

\footnotetext{
${ }^{4}$ This argument is particularly applicable to the precision interpretation of overconfidence: Precision will be more similar the better is the information.

${ }^{5}$ The implication of information asymmetries is less straightforward if we allow for information asymmetry between bidder and target boards with respect to synergies: bidder board members may be better informed than target counterparts about potential synergies. In such a case the outcome depends on the relative magnitudes of the target board members' information advantage concerning their firm versus the bidder board members' information advantage concerning synergies. Ultimately, it is an empirical question.
} 


$$
\begin{aligned}
& \log \left(\text { Bid initiation }_{i t}\right)=\alpha_{0}+\beta_{1} \text { Fraction of female directors }{ }_{i t}+\beta_{2} \text { Board }_{\text {size }}{ }_{i t} \\
& +\beta_{3} \text { Fraction of independen } t \text { directors }{ }_{i t}+\beta_{4} \text { CEO being } C O B_{i t} \\
& +\beta_{5} \text { Sales growth }{ }_{i t}+\beta_{6} \text { Tobin's } Q_{i t}+\beta_{7} \text { ROA }_{i t}+\beta_{8} \text { Book leverage }_{i t} \\
& +\beta_{9} \text { Cashholdin } g_{i t}+\beta_{10} \text { Firm size }_{i t}+e_{\mathrm{i} t} \text {. }
\end{aligned}
$$

where bid initiation is the number of acquisition bids made within a fiscal year. The number of bid initiations is an over-dispersed count variable, whose variance is significantly greater than its mean (see Figure 1 and Table 1). In this case, the Negative Binomial regression will produce consistent estimation results (Cameron and Trivedi (1998)).

The key explanatory variable of interest is the measure of board gender diversity in sample firms. The controls for firm characteristics are motivated by Byrd and Hickman (1992), Shivdasani (1993), and Levi, Li, and Zhang (2010). We also control for year and industry fixed effects (based on Fama-French (1997) 48-industry classifications). Because standard errors may be underestimated in panel data sets like ours, we present results based on standard errors clustered by firm (Petersen (2009)).

\section{II.B. The Bid Initiation Sample}

To form the bid initiation sample, we start with firms covered by Compustat/CRSP and the RiskMetrics Group's corporate board and director database (covering member firms in the S\&P 500 index, the S\&P MidCap 400 index, and the S\&P SmallCap 600 index-hence S\&P 1500 firms). We then retrieve the acquisition bids initiated by these firms during 1997-2009 from the Thomson Financial's SDC database. We require an acquisition bid to take the form of a merger (SDC deal form M), acquisition of majority interest (AM), and acquisition of assets (AA). We include control bids only where the bidder's toehold before the deal announcement is less than 50 percent, and the sum of the toehold and the percentage ownership sought in the deal is greater than 50 percent. The board and director information is taken from RiskMetrics at the 
most recent annual shareholder meetings before the bid announcement. Our final bid initiation sample consists of 19,619 firm-year observations.

Panel A of Table 1 presents the descriptive statistics of the variables. The average number of acquisition bids initiated by a firm in any year is 0.57 . The number of bid initiations is over-dispersed with a variance of 1.73 . About 70 percent of the firm-years have no bid, 18 percent have one bid, and 6.5 percent have two bids (Figure 1). The average corporate board consists of 9.5 members, of which 9.5 percent are women and 67.4 percent are independent outsiders. These numbers are slightly higher than those reported in the study by Farrell and Hersch (2005) who show that female directors comprise 8.6 percent of board members in a sample of Fortune 500 firms, and in the study by Paul (2007) who shows that independent directors comprise 53 percent of board members in a sample of M\&A deals over the period 1982-1996.

About 62.2 percent of the CEOs are also Chairman of the Board. The average sales growth is 13.1 percent; Tobin's Q 1.9; return on assets 4.0 percent; and book leverage 23.7 percent. On average, 13.1 percent of the assets of the firms in our sample are in the form of cash or short-term investments. The firms have an average market capitalization of $\$ 7.6$ billion.

Panel B of Table 1 presents the correlation matrix of the variables. We show that the fraction of female directors on a corporate board is positively but insignificantly correlated with the number of acquisition bids, while the indicator variable for multiple female directors is positively and significantly correlated with the number of acquisition bids. Given that omitted variable bias in univariate correlations can mask the true relations between the variables, next we employ multiple regressions to examine the determinants of corporate acquisitiveness. 


\section{II.C. Main Findings}

Panel C of Table 1 presents the Negative Binomial regression results where the dependent variable is the number of bids. We find that the fraction of female directors on the board is negatively and significantly associated with the number of bids. In terms of the economic significance, each ten-percent representation of female directors on the board, corresponding to approximately one female director, reduces the number of bids by 7.5 percent $(=1-\exp (-0.7831 \times 0.1))$. The first term in the exponential function is the coefficient on the fraction of female directors. This finding is consistent with the less overconfident nature of women. Specifically, a less acquisitive board with female directors would result from less overconfidence: women have a less precise and/or more conservative view of the value of an acquisition, and would consequently be less inclined to favor it. That is, documented behavior associated with women in other contexts has the predicted economically and statistically significant association with the propensity of companies to pursue M\&As.

Our findings in this paper are consistent with those in Levi, Li, and Zhang (2010) based on the male-dominance hormone, testosterone. By proxying the quantity of the hormone by age, they find higher implied testosterone across a population of male CEOs is positively associated with greater acquisitiveness. It is worth noting that our main findings on board gender diversity remain unchanged when using an indicator variable to capture acquisitiveness in the same way as Malmendier and Tate (2008), and Levi et al. (2010).

As a robustness check to our main findings, we also introduce two indicator variables to capture a potential non-linear association between female representation on the board of directors and acquisitiveness: 'bidder one female director' takes the value of one if a bidder firm has only one female director, and zero otherwise; and 'bidder multiple female directors' takes the value of 
one if a bidder firm has more than one female director, and zero otherwise. Panel C Column (2) of Table 1 shows that both female director indicator variables are negatively and significantly associated with the number of bids. In terms of the economic significance, having a lone (more than one) female director on the bidder board reduces the number of bids by 11.4 (21.1) percent. The board gender effect on acquisitiveness is highly non-linear, which is consistent with either female directors feeling more comfortable expressing their less favorable opinion about pursuing an acquisition when there are other female directors present, or their dissenting opinion being taken more seriously when there are multiple female directors with the same point of view.

In addition to the above main findings, we show that the larger is a firm, and the lower is its leverage and its cash holdings, the more acquisitive it is likely to be.

\section{Gender Diversity and Bid Premium}

We next consider the association between board composition and the size of the bid premium.

\section{III.A. Model Specification}

To explore the possible association between board gender diversity and bid premiums in M\&As we run the following cross-sectional regression:

Bid Premium $_{i}=\alpha_{0}+\beta_{1}$ Bidder fraction of female directors ${ }_{i}+\beta_{2}$ Target fraction of female directors ${ }_{i}$

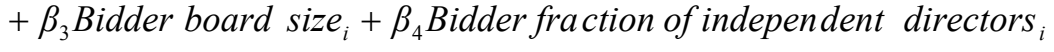

$+\beta_{5}$ Bidder CEO being $C O B_{i}+\beta_{6}$ Target board size ${ }_{i}$

$+\beta_{7}$ Target fraction of indepen dent directors ${ }_{i}$

$+\beta_{8}$ Target CEO being $\mathrm{COB}_{i}+$ Other Controls $+e_{i}$,

where the key explanatory variable of interest is the measure of board gender diversity in the bidder firms. The governance-related variables and controls for deal- and firm- characteristics 
are motivated by Byrd and Hickman (1992), Shivdasani (1993), Cotter, Shivdasani, and Zenner (1997), Bange and Mazzeo (2004), and Chen, Harford, and Li (2007). Deal characteristics include the toehold, as well as indicator variables for all cash deals, all stock deals, tender offers, and unfriendly deals. Bidder/target firm characteristics include sales growth, Tobin's Q, return on assets (ROA), and book leverage. We include year fixed effects and industry fixed effects, and we employ robust standard errors.

\section{III.B. The Mergers and Acquisitions Sample}

To form our mergers and acquisitions sample, we start with the acquisition bids made by US public companies for US public targets between January 1, 1997 and December 31, 2009 covered in the Thomson Financial's SDC database, and we impose the same filters on deal types, and initial and final ownership as our bid initiation sample. We end up with 5,301 deals. Data requirements on deal characteristics such as bid premium and transaction value further reduce the number of deals in our sample to 2,679. These deals are then merged with the RiskMetrics Group's corporate board and director database. These steps reduce our sample to 470 deals. Firm characteristics and stock returns are retrieved from Compustat and CRSP. Our final mergers and acquisitions sample consists of 458 acquisition bids.

Table 2 shows that in our sample the average bid premium is 35 percent. Bid premium is defined as the ratio of the final offer price to the target stock price four weeks prior to the bid minus one. On average, about 11 percent of bidder directors are female, with the proportion of female directors ranging from zero at the $5^{\text {th }}$ percentile to 25 percent at the $95^{\text {th }}$ percentile. On average, about 8 percent of target directors are female. 
On average, the bidder firms own 0.6 percent of their targets before the bid announcement. In 19 percent of the acquisitions in our sample, the bidder pays the target with cash only, while 35 percent of the bidders pay in equity only. Overall, the deal characteristics in our sample are not very different from much larger samples covering earlier periods.

Table 3 presents the correlation matrix. We show that both the proportion of female directors on a bidder board and the indicator variable for target one female director are negatively and significantly correlated with the bid premium. Overall, the extent of correlation among all pairs of control variables raises little concern for multicollinearity in our regression analysis.

\section{III.C. Female Directors and Bid Premium}

Table 4 presents the OLS regression results where the dependent variable is the size of the bid premium. In Column (1) we find that gender diversity on the bidder board, as measured by the fraction of female directors, is significantly and negatively associated with the size of the bid premium. In terms of the economic significance, each ten-percent representation of female directors on the bidder board, corresponding to approximately one female director, reduces the size of the bid premium by 13.3 percent $(=0.10 \times 0.47 / 0.35)$. The second term in the numerator is the coefficient on the bidder fraction of female directors, and the denominator is the sample mean bid premium as shown in Table 2. There is no significant association between female directors on the target board and the size of the bid premium. Interest in selling high and/or a lack of target male versus female director asymmetry of information about target value would lead us to expect this result. 
In Column (2), we add controls for the nature of the bid as well as the relative size of the target firm, and find that gender diversity on the bidder board remains negatively and significantly correlated with the size of the bid premium.

In Column (3), we measure female representation using two indicator variables as defined before. We show that both female director indicator variables are negatively and significantly associated with the size of the bid premium. In terms of the economic significance, having a lone (more than one) female director on the bidder board reduces the size of the bid premium by $22.6(32.6)$ percent.

In addition to the main findings above, we show that bids made by better performing bidders and tender offers are positively associated with the size of the bid premium.

\section{Additional Investigation}

\section{IV.A. Controlling for Equity Ownership and Incentives}

It can be argued that the significant association between board gender diversity and M\&As uncovered in this paper could be driven by the directors' economic interests associated with an M\&A transaction. To separate the gender effect from directors' financial interests, we need to control for director equity ownership and compensation.

The data on director ownership and compensation in the ExecuComp database is quite limited prior to 2006. As a result, the sample size of our bid initiation sample decreases from 19,619 to 17,979 firm-year observations (for data on director ownership) and to 17,958 firm-year observations (for data on director compensation). There is very little equity ownership by individual directors on either the bidder or the target board, so for each we sum up individual directors' equity ownership to obtain equity ownership by all directors. Further, given the poor 
data quality on director equity-based pay, we introduce an indicator variable that takes the value of one if there is any equity-based pay for the directors, and zero otherwise. Table 1 Panel A shows that the average director ownership is 9.0 percent and about 89 percent of boards are paid with equity.

Similarly, our mergers and acquisitions sample is reduced from 458 observations to 315 observations with information on both the bidder and target director ownership and compensation. Table 2 shows that the average ownership by bidder directors is 5.6 percent, while the average ownership by target directors is 7.4 percent. About 88 percent ( 86 percent) of bidder (target) directors are paid with equity. These numbers in Tables 1 and 2 are largely consistent with each other.

Table 5 Panel A investigates the robustness of our results on bid initiation. Columns (1)(2) show that director ownership is negatively and significantly associated with the number of bids, while director equity-based pay is not significantly associated with the number of bids. Importantly, after controlling for director equity ownership and equity-based pay, gender diversity is still negatively and significantly associated with the number of initiated bids. In terms of the economic significance, each ten-percent representation of female directors on the board reduces the number of bid initiations by 7.0 percent.

Table 5 Panel B investigates the robustness of our results on the bid premium. Columns (1)-(2) show that neither director equity ownership nor equity-based pay is significantly associated with the size of the bid premium. Importantly, after controlling for director equity incentives, there remains a strong and significant association between gender diversity and the size of the bid premium. As before, the association found in the context of M\&As is consistent 
with the growing body of evidence in other areas of enquiry that women are less overconfident than men.

\section{IV.B. Distinguishing between Independent and Dependent Female Directors}

Prior work such as Byrd and Hickman (1992), Shivdasani (1993), Cotter, Shivdasani, and Zenner (1997), Hermalin and Weisbach (1998), and Paul (2007) has shown that boards dominated by independent directors are more likely to make decisions that are in the interest of shareholders. If independence of directors matters, we expect M\&A terms and outcomes to differ depending on whether a female director is an independent or a dependent director. Thus we break down the fraction of female directors into the fraction of independent female directors and the fraction of dependent female directors.

In our bid initiation sample (see Table 1 Panel A), female directors primarily come from outside, consistent with findings in Farrell and Hersch (2005). On average, the fraction of independent female directors on the bidder board is 8.2 percent, compared to the fraction of all female directors, which is 9.5 percent of the bidder board; hence the average fraction of dependent female directors on the bidder board is only about one percent. The distribution of independent and dependent female directors on the bidder and target boards for firms in the mergers and acquisitions sample is similar (see Table 2).

In Column (3) of Table 5 Panel A, we replace the fraction of female directors in Equation (1) with the fractions of independent and dependent female directors (relative to board size) to check the robustness of our findings on gender diversity and bid initiation. We show that both independent and dependent female directors are significantly and negatively associated with the 
number of bid initiations. Each ten-percent representation of independent (dependent) female directors on the board reduces the number of initiated bids by 6.3 (12.9) percent.

In Column (3) of Table 5 Panel B, we show that each ten-percent representation of independent (dependent) female directors on the board reduces the bid premium by 11.1 (24.1) percent. Both associations are statistically significant at the ten-percent and five-percent levels, respectively.

As mentioned at the outset, one caveat to our results is the issue of endogeneity. Observable personal characteristics such as employment and educational background could be a large part of the selection criteria for directors. CEOs may even take gender differences in overconfidence into account when recommending directors to shareholders. We are able to alleviate some endogeneity concerns with additional controls. We show that our results are not driven by industry effects, firm characteristics such as size and growth opportunities, or director characteristics such as independence and equity incentives. Further, even if a female director is chosen because of her relatively low overconfidence, the CEO should be aware of this personal trait and take steps to explicitly address it. If that is the case, the observed outcome of a lower frequency of acquisition deals and lower prices paid can be traced back to female board members being less overconfident than male board members. As such, we still have reason to conclude that there is a significant association between female representation on corporate boards and M\&As.

\section{Conclusions}

Consistent with evidence in other finance contexts such as investment, trading, and corporate performance, we have found a further important association between gender diversity 
on corporate boards and the functioning of boards in the economically important arena of M\&As. This arena is particularly fitting as it involves decisions that lack fast, clear feedback, and due to the fact that unlike day-to-day operating decisions, M\&As are major corporate events that involve direct and intensive deliberation among board members.

Using acquisition bids initiated by S\&P 1500 firms during the period 1997-2009, we show that female directors appear less interested in empire building than their male counterparts: their presence on the corporate board is negatively associated with their firms' acquisitiveness. Furthermore, using data from over 450 acquisition bids for which we have the necessary information on the bidder and target firms, we show that the representation of female directors on a bidder board is negatively and significantly associated with the size of the bid premium. As expected, there is no effect of female directors on a target board on the size of the bid premium.

Our findings are consistent with women being less overconfident than men, as documented by Barber and Odean (2001) and many others (see the survey by Croson and Gneezy (2009)). With increasing discussion of legislative requirements for more equal female representation on corporate boards around the world (Ahern and Dittmar (2011), and Masta and Miller (2011a)), the evidence from studying mergers and acquisitions becomes of considerable economic, political, and social importance. 


\section{Appendix:}

\section{Definition of Variables}

\begin{tabular}{|c|c|}
\hline Variable & Definition \\
\hline \# M\&A bid initiations & $\begin{array}{l}\text { The number of bids initiated by a firm within a fiscal year. The bid } \\
\text { shall take the form of a merger (SDC deal form M), acquisition of } \\
\text { majority interest (AM), or acquisition of assets (AA). Also, we } \\
\text { include only control bids where the bidder's toehold before the } \\
\text { deal announcement is less than } 50 \text { percent, and the sum of the } \\
\text { toehold and the percentage ownership sought in the deal is greater } \\
\text { than } 50 \text { percent. }\end{array}$ \\
\hline Fraction of female directors & The number of female directors divided by the board size. \\
\hline One female director & $\begin{array}{l}\text { An indicator variable that takes the value of one if there is exactly } \\
\text { one female director on the board, and zero otherwise. }\end{array}$ \\
\hline Multiple female directors & $\begin{array}{l}\text { An indicator variable that takes the value of one if there are at least } \\
\text { two female directors on the board, and zero otherwise. }\end{array}$ \\
\hline $\begin{array}{l}\text { Fraction of independent } \\
\text { directors }\end{array}$ & The number of independent directors divided by the board size. \\
\hline CEO being $\mathrm{COB}$ & $\begin{array}{l}\text { An indicator variable taking the value of one if the } \mathrm{CEO} \text { is also the } \\
\text { Chairman of the Board (COB), and zero otherwise. }\end{array}$ \\
\hline Board size & The number of directors serving on the board. \\
\hline Sales growth & $\begin{array}{l}\text { The ratio of sales (data item sale in Compustat) in the current } \\
\text { fiscal year to sales in the last year minus one. }\end{array}$ \\
\hline Tobin's Q & $\begin{array}{l}\text { The market value of total assets divided by the book value of total } \\
\text { assets. Market value of assets is calculated as book value of total } \\
\text { assets (data item at in Compustat) minus book value of common } \\
\text { equity (ceq) plus common shares outstanding (csho) times stock } \\
\text { price ( }(\text { r ccc ff). }\end{array}$ \\
\hline ROA & $\begin{array}{l}\text { Income before extraordinary items (data item } i b \text { in Compustat) } \\
\text { divided by the book value of total assets (at) at the beginning of } \\
\text { the fiscal year. }\end{array}$ \\
\hline Book leverage & $\begin{array}{l}\text { The sum of debt in current liabilities (data item } d l c \text { in Compustat) } \\
\text { plus long-term liabilities }(d l t t) \text { divided by the book value of total } \\
\text { assets }(a t) \text {. }\end{array}$ \\
\hline Cashholding & $\begin{array}{l}\text { Cash and short-term investments (data item che in Compustat) } \\
\text { divided by book value of total assets }(a t) \text {. }\end{array}$ \\
\hline Market capitalization & $\begin{array}{l}\text { Common shares outstanding (data item } c s h o \text { in Compustat) times } \\
\text { stock price }(\operatorname{prcc} f) \text {. }\end{array}$ \\
\hline Ownership of directors & $\begin{array}{l}\text { The aggregate ownership of the directors. The data are from the } \\
\text { RiskMetrics database. }\end{array}$ \\
\hline Director paid with equity & $\begin{array}{l}\text { An indicator variable taking the value of one if the directors are } \\
\text { paid with stocks and/or stock options, and zero otherwise. The data } \\
\text { are retrieved from the ExecuComp database. }\end{array}$ \\
\hline $\begin{array}{l}\text { Fraction of independent } \\
\text { female directors }\end{array}$ & $\begin{array}{l}\text { The number of independent female directors divided by the board } \\
\text { size. }\end{array}$ \\
\hline
\end{tabular}


Fraction of dependent female directors

Bid premium

Toehold

All cash

All stock

Tender offer

Unfriendly

Relative size
The number of dependent female directors divided by the board size.

The ratio of the final offer price to the target stock price four weeks prior to the original announcement date minus one. The proportion of the target firm's shares owned by the bidder before the bid announcement.

An indicator variable taking the value of one if only cash is used to pay for the acquisition, and zero otherwise.

An indicator variable taking the value of one if only equity is used to pay for the acquisition, and zero otherwise.

An indicator variable taking the value of one if SDC regards the bid as a tender offer, and zero otherwise.

An indicator variable taking the value of one if SDC regards the deal as unfriendly, and zero otherwise.

The transaction value divided by the market value of total assets of the bidder at the fiscal year end prior to the bid announcement. Market value of assets is calculated as book value of total assets (data item at in Compustat) minus book value of common equity (ceq) plus common shares outstanding (csho) times stock price $(\operatorname{prcc} f)$. 


\section{References:}

Adams, Renée B., and Daniel Ferreira, 2009, Women in the boardroom and their impact on governance and performance, Journal of Financial Economics 94, 291-309.

Ahern, Kenneth R., and Amy K. Dittmar, 2011, The changing of the boards: The impact on firm valuation of mandated female board representation, Quarterly Journal of Economics forthcoming.

Andrade, Gregor, Mark Mitchell, and Erik Stafford, 2001, New evidence and perspectives on mergers, Journal of Economic Perspectives 15, 103-120.

Atkinson, Stanley M., Samantha B. Baird, and Melissa B. Frye, 2003, Do female mutual fund managers manage differently? Journal of Financial Research 26, 1-18.

Bange, Mary M., and Michael A. Mazzeo, 2004, Board composition, board effectiveness, and the observed form of takeover bids, Review of Financial Studies 17, 1185-1215.

Barber, Brad M., and Terrance Odean, 2001, Boys will be boys: Gender, overconfidence, and common stock investment, Quarterly Journal of Economics 116, 261-292.

Beyer, Sylvia, 1990, Gender differences in the accuracy of self-evaluations of performance, Journal of Personality and Social Psychology 59, 960-970.

Byrd, John W., and Kent A. Hickman, 1992, Do outside directors monitor managers? Journal of Financial Economics 32, 195-221.

Cameron, A. Collin, and Pravin K. Trivedi, 1998, Regression Analysis of Count Data. New York: Cambridge University Press.

Chen, Xia, Jarrad Harford, and Kai Li, 2007, Monitoring: Which institutions matter? Journal of Financial Economics 86, 279-305.

Cotter, James F., Anil Shivdasani, and Marc Zenner, 1997, Do independent directors enhance target shareholder wealth during tender offers? Journal of Financial Economics 43, 195 218.

Croson, Rachel, and Uri Gneezy, 2009, Gender differences in preferences, Journal of Economic Literature 47, 448-474.

Deaves, Richard, Erik Lüders, and Guo Ying Luo, 2009, An experimental test of the impact of overconfidence and gender on trading activity, Review of Finance 13, 555-575.

Dwyer, Peggy D., James H. Gilkeson, and John A. List, 2002, Gender differences in revealed risk taking: evidence from mutual fund investors, Economic Letters 76, 151-158. 
Fama, Eugene, and Kenneth French, 1997, Industry costs of equity, Journal of Financial Economics 43, 153-193.

Farrell, Kathleen A., and Phillip L. Hersch, 2005, Additions to corporate boards: The effect of gender, Journal of Corporate Finance 11, 85-106.

Hermalin, Benjamin E., and Michael S. Weisbach, 1998, Endogenously chosen boards of directors and their monitoring of the CEO, American Economic Review 88, 96-118.

Jensen, Michael, 1986, Agency costs of free cash flow, corporate finance, and takeovers, American Economic Review 76, 323-329.

Jensen, Michael, 1988, Takeovers: Their causes and consequences, Journal of Economic Perspectives 2, 21-48.

Knight, Jonathan, 2002, Sexual stereotypes, Nature 415, 254-256.

Langer, Ellen J., 1975, The illusion of control, Journal of Personality and Social Psychology 2, 311-328.

Lenney, Ellen, 1977, Women's self-confidence in achievement settings, Psychological Bulletin $84,1-13$.

Levi, Maurice, Kai Li, and Feng Zhang, 2010, Deal or no deal: Hormones and the mergers and acquisitions game, Management Science 56, 1462-1483.

Lichtenstein, Sarah, Baruch Fischhoff, and Lawrence Phillips, 1982, Calibration of probabilities: The state of the art to 1980, In Judgment under Uncertainty: Heuristics and Biases, Daniel Kahneman, Paul Slovic, and Amos Tversky, eds. 306-344, New York: Cambridge University Press.

Malmendier, Ulrike, and Geoffrey Tate, 2005, CEO overconfidence and corporate investment, Journal of Finance 60, 2661-2700.

Malmendier, Ulrike, and Geoffrey Tate, 2008, Who makes acquisitions? CEO overconfidence and the market's reaction, Journal of Financial Economics 89, 20-43.

Matsa, David A., and Amalia R. Miller, 2011a, A female style in corporate leadership? Evidence from quotas, Unpublished working paper.

Matsa, David A., and Amalia R. Miller, 2011b, Chipping away at the glass ceiling: Gender spillovers in corporate leadership, American Economic Review 101, 635-639.

Paul, Donna L., 2007, Board composition and corrective action: Evidence from corporate responses to bad acquisition bids, Journal of Financial and Quantitative Analysis 42, 759-784. 
Petersen, Mitchell A., 2009, Estimating standard errors in finance panel data sets: Comparing approaches, Review of Financial Studies 22, 435-480.

Sapienza, Paola, Luigi Zingales, and Dario Maestripieri, 2009, Gender differences in financial risk aversion and career choices are affected by testosterone, Proceedings of the National Academy of Sciences 106, 15268-15273.

Sax, Leonard, 2005, Why gender matters, New York: Doubleday.

Shivdasani, Anil, 1993, Board composition, ownership structure, and hostile takeovers, Journal of Accounting and Economics 16, 167-198.

Sundén, Annika E., and Brian J. Surette, 1998, Gender differences in the allocation of assets in retirement savings plan, American Economic Review 88, 207-211. 


\section{Figure 1}

Histogram of the Number of Bid Initiations

This figure plots the histogram of the number of acquisition bids initiated by the firms in our sample in each year over the period 1997-2009. Our sample consists of 19,619 firm-year observations. The sample is retrieved from Compustat/CRSP and has available data on board characteristics from RiskMetrics.

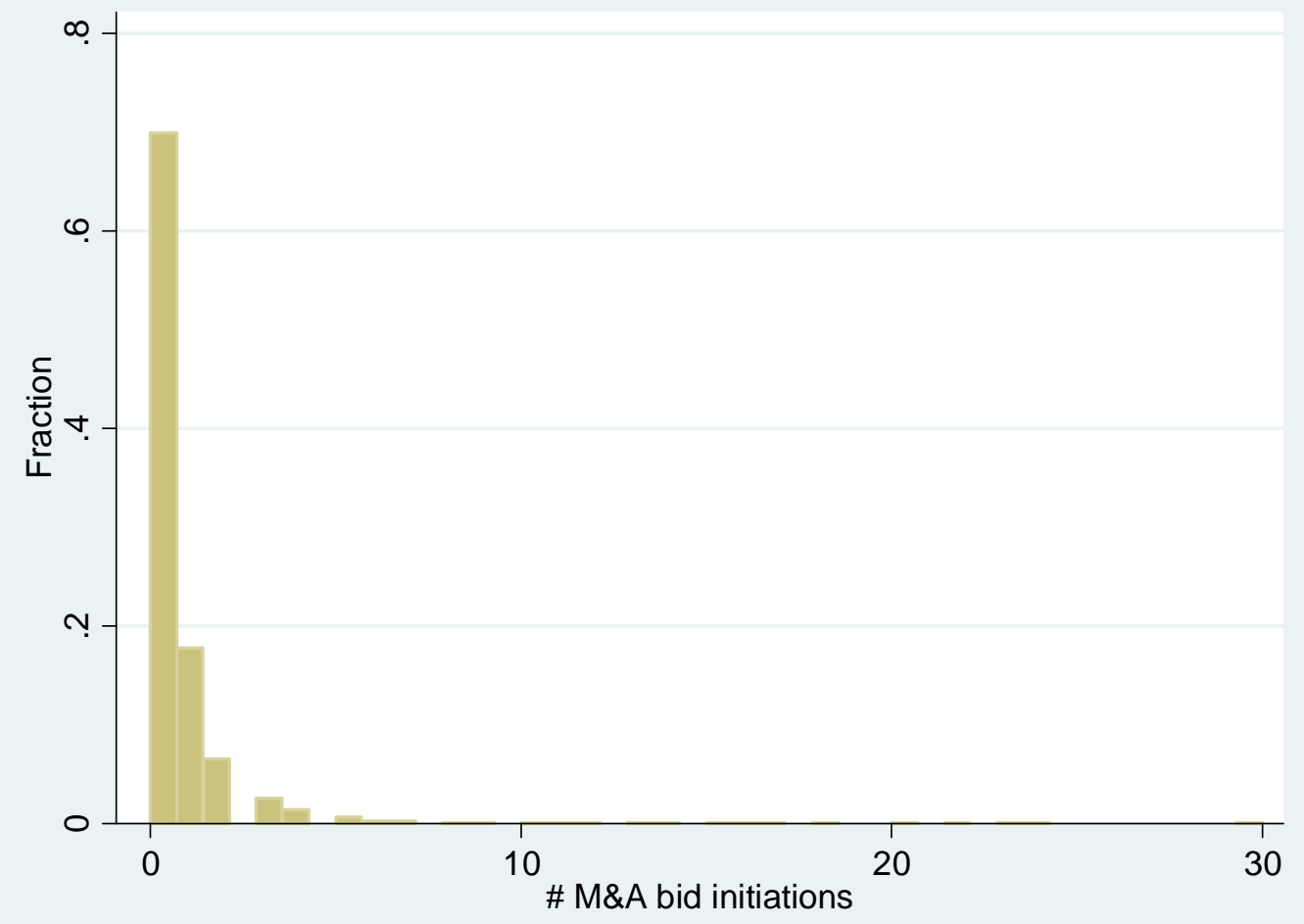


Table 1

Bid Initiation

Our bid initiation sample consists of 19,619 firm-year observations during the period 1997-2009. The sample is retrieved from Compustat/CRSP and has available data on board characteristics from RiskMetrics. All firm characteristics are measured at the fiscal year end prior to the bid announcement date. See the Appendix for definition of the variables. All percentages are in decimal format. Panel A presents the summary statistics. Panel B presents the correlation matrix. Panel C presents the Negative Binomial regression results for the number of bid initiations. All model specifications employ robust standard errors clustered by firm, which are reported in the parentheses below each coefficient. Superscripts ***,**, and * correspond to statistical significance at the one, five, and ten percent levels, respectively.

Panel A: Summary Statistics of the Bid Initiation Sample

\begin{tabular}{lrrrrrr} 
Variable & $\mathrm{N}$ & Mean & StdDev & Percentile & Median & $\begin{array}{r}5^{\text {th }} \\
\text { Percentile }\end{array}$ \\
\hline \# M\&A bid initiations & 19619 & 0.570 & 1.314 & 0.000 & 0.000 & 3.000 \\
Fraction of female directors & 19619 & 0.095 & 0.092 & 0.000 & 0.100 & 0.250 \\
One female director & 19619 & 0.379 & 0.485 & 0.000 & 0.000 & 1.000 \\
Multiple female directors & 19619 & 0.251 & 0.434 & 0.000 & 0.000 & 1.000 \\
Board size & 19619 & 9.469 & 2.811 & 6.000 & 9.000 & 14.000 \\
Fraction of independent directors & 19619 & 0.674 & 0.177 & 0.333 & 0.706 & 0.900 \\
CEO being COB & 19619 & 0.622 & 0.485 & 0.000 & 1.000 & 1.000 \\
Sales growth & 19619 & 0.131 & 2.739 & -0.241 & 0.074 & 0.534 \\
Tobin's Q & 19619 & 1.891 & 1.621 & 0.922 & 1.438 & 4.300 \\
ROA & 19619 & 0.040 & 0.258 & -0.120 & 0.044 & 0.181 \\
Book leverage & 19619 & 0.237 & 0.192 & 0.000 & 0.223 & 0.567 \\
Cashholding & 19619 & 0.131 & 0.163 & 0.004 & 0.060 & 0.496 \\
Market capitalization (\$B) & 19619 & 7.636 & 24.295 & 0.154 & 1.607 & 30.099 \\
Ownership of directors & 17979 & 0.090 & 0.134 & 0.003 & 0.035 & 0.376 \\
Directors paid with equity & 17958 & 0.891 & 0.312 & 0.000 & 1.000 & 1.000 \\
Fraction of independent female directors & 19619 & 0.082 & 0.085 & 0.000 & 0.091 & 0.231 \\
Fraction of dependent female directors & 19619 & 0.012 & 0.038 & 0.000 & 0.000 & 0.111 \\
\hline
\end{tabular}




\section{Panel B: Correlation Matrix}

\begin{tabular}{|c|c|c|c|c|c|c|c|c|c|c|c|c|c|c|c|c|c|c|}
\hline & & 1 & 2 & 3 & 4 & 5 & 6 & 7 & 8 & 9 & 10 & 11 & 12 & 13 & 14 & 15 & 16 & 17 \\
\hline 1 & \# M\&A bid initiations & 1.00 & & & & & & & & & & & & & & & & \\
\hline 2 & Fraction of female directors & $\begin{array}{l}0.00 \\
{[0.98]}\end{array}$ & 1.00 & & & & & & & & & & & & & & & \\
\hline 3 & One female director & $\begin{array}{l}0.01 \\
{[0.34]}\end{array}$ & $\begin{array}{l}0.12 \\
{[0.00]}\end{array}$ & 1.00 & & & & & & & & & & & & & & \\
\hline 4 & Multiple female directors & $\begin{array}{l}0.01 \\
{[0.05]}\end{array}$ & $\begin{array}{l}0.75 \\
{[0.00]}\end{array}$ & $\begin{array}{l}-0.45 \\
{[0.00]}\end{array}$ & 1.00 & & & & & & & & & & & & & \\
\hline 5 & Board size & $\begin{array}{l}0.08 \\
{[0.00]}\end{array}$ & $\begin{array}{l}0.24 \\
{[0.00]}\end{array}$ & $\begin{array}{l}0.08 \\
{[0.00]}\end{array}$ & $\begin{array}{l}0.38 \\
{[0.00]}\end{array}$ & 1.00 & & & & & & & & & & & & \\
\hline 6 & Fraction of independent directors & $\begin{array}{l}-0.03 \\
{[0.00]}\end{array}$ & $\begin{array}{l}0.24 \\
{[0.00]}\end{array}$ & $\begin{array}{l}0.05 \\
{[0.00]}\end{array}$ & $\begin{array}{l}0.21 \\
{[0.00]}\end{array}$ & $\begin{array}{l}0.09 \\
{[0.00]}\end{array}$ & 1.00 & & & & & & & & & & & \\
\hline 7 & CEO being $\mathrm{COB}$ & $\begin{array}{l}0.02 \\
{[0.00]}\end{array}$ & $\begin{array}{l}0.07 \\
{[0.00]}\end{array}$ & $\begin{array}{l}0.00 \\
{[0.50]}\end{array}$ & $\begin{array}{l}0.07 \\
{[0.00]}\end{array}$ & $\begin{array}{l}0.05 \\
{[0.00]}\end{array}$ & $\begin{array}{l}0.07 \\
{[0.00]}\end{array}$ & 1.00 & & & & & & & & & & \\
\hline 8 & Sales growth & $\begin{array}{l}0.02 \\
{[0.01]}\end{array}$ & $\begin{array}{l}0.00 \\
{[0.83]}\end{array}$ & $\begin{array}{l}-0.01 \\
{[0.18]}\end{array}$ & $\begin{array}{l}0.01 \\
{[0.44]}\end{array}$ & $\begin{array}{l}0.00 \\
{[0.91]}\end{array}$ & $\begin{array}{l}-0.01 \\
{[0.04]}\end{array}$ & $\begin{array}{l}0.01 \\
{[0.34]}\end{array}$ & 1.00 & & & & & & & & & \\
\hline 9 & Tobin's Q & $\begin{array}{l}0.10 \\
{[0.00]}\end{array}$ & $\begin{array}{l}-0.02 \\
{[0.00]}\end{array}$ & $\begin{array}{l}-0.02 \\
{[0.01]}\end{array}$ & $\begin{array}{l}-0.03 \\
{[0.00]}\end{array}$ & $\begin{array}{l}-0.14 \\
{[0.00]}\end{array}$ & $\begin{array}{l}-0.07 \\
{[0.00]}\end{array}$ & $\begin{array}{l}-0.02 \\
{[0.01]}\end{array}$ & $\begin{array}{l}0.03 \\
{[0.00]}\end{array}$ & 1.00 & & & & & & & & \\
\hline 10 & ROA & $\begin{array}{l}0.03 \\
{[0.00]}\end{array}$ & $\begin{array}{l}0.04 \\
{[0.00]}\end{array}$ & $\begin{array}{l}0.02 \\
{[0.01]}\end{array}$ & $\begin{array}{l}0.03 \\
{[0.00]}\end{array}$ & $\begin{array}{l}0.02 \\
{[0.01]}\end{array}$ & $\begin{array}{l}0.01 \\
{[0.24]}\end{array}$ & $\begin{array}{l}0.01 \\
{[0.09]}\end{array}$ & $\begin{array}{l}0.73 \\
{[0.00]}\end{array}$ & $\begin{array}{l}0.12 \\
{[0.00]}\end{array}$ & 1.00 & & & & & & & \\
\hline 11 & Book leverage & $\begin{array}{l}-0.05 \\
{[0.00]}\end{array}$ & $\begin{array}{l}0.06 \\
{[0.00]}\end{array}$ & $\begin{array}{l}0.01 \\
{[0.23]}\end{array}$ & $\begin{array}{l}0.07 \\
{[0.00]}\end{array}$ & $\begin{array}{l}0.13 \\
{[0.00]}\end{array}$ & $\begin{array}{l}-0.01 \\
{[0.23]}\end{array}$ & $\begin{array}{l}0.06 \\
{[0.00]}\end{array}$ & $\begin{array}{l}0.00 \\
{[0.92]}\end{array}$ & $\begin{array}{l}-0.18 \\
{[0.00]}\end{array}$ & $\begin{array}{l}-0.08 \\
{[0.00]}\end{array}$ & 1.00 & & & & & & \\
\hline 12 & Cashholding & $\begin{array}{l}0.00 \\
{[0.69]}\end{array}$ & $\begin{array}{l}-0.11 \\
{[0.00]}\end{array}$ & $\begin{array}{l}-0.08 \\
{[0.00]}\end{array}$ & $\begin{array}{l}-0.12 \\
{[0.00]}\end{array}$ & $\begin{array}{l}-0.29 \\
{[0.00]}\end{array}$ & $\begin{array}{l}-0.02 \\
{[0.00]}\end{array}$ & $\begin{array}{l}-0.08 \\
{[0.00]}\end{array}$ & $\begin{array}{l}0.00 \\
{[0.81]}\end{array}$ & $\begin{array}{l}0.34 \\
{[0.00]}\end{array}$ & $\begin{array}{l}-0.01 \\
{[0.04]}\end{array}$ & $\begin{array}{l}-0.36 \\
{[0.00]}\end{array}$ & 1.00 & & & & & \\
\hline 13 & Logarithm of market capitalization & $\begin{array}{l}0.21 \\
{[0.00]}\end{array}$ & $\begin{array}{l}0.26 \\
{[0.00]}\end{array}$ & $\begin{array}{l}0.05 \\
{[0.00]}\end{array}$ & $\begin{array}{l}0.31 \\
{[0.00]}\end{array}$ & $\begin{array}{l}0.44 \\
{[0.00]}\end{array}$ & $\begin{array}{l}0.15 \\
{[0.00]}\end{array}$ & $\begin{array}{l}0.11 \\
{[0.00]}\end{array}$ & $\begin{array}{l}0.02 \\
{[0.00]}\end{array}$ & $\begin{array}{l}0.25 \\
{[0.00]}\end{array}$ & $\begin{array}{l}0.12 \\
{[0.00]}\end{array}$ & $\begin{array}{l}0.00 \\
{[0.64]}\end{array}$ & $\begin{array}{l}-0.06 \\
{[0.00]}\end{array}$ & 1.00 & & & & \\
\hline 14 & Ownership of directors & $\begin{array}{l}-0.04 \\
{[0.00]}\end{array}$ & $\begin{array}{l}-0.12 \\
{[0.00]}\end{array}$ & $\begin{array}{l}-0.05 \\
{[0.00]}\end{array}$ & $\begin{array}{l}-0.11 \\
{[0.00]}\end{array}$ & $\begin{array}{l}-0.10 \\
{[0.00]}\end{array}$ & $\begin{array}{l}-0.41 \\
{[0.00]}\end{array}$ & $\begin{array}{l}-0.06 \\
{[0.00]}\end{array}$ & $\begin{array}{l}0.00 \\
{[0.72]}\end{array}$ & $\begin{array}{l}0.05 \\
{[0.00]}\end{array}$ & $\begin{array}{l}-0.01 \\
{[0.18]}\end{array}$ & $\begin{array}{l}-0.05 \\
{[0.00]}\end{array}$ & $\begin{array}{l}0.06 \\
{[0.00]}\end{array}$ & $\begin{array}{l}-0.19 \\
{[0.00]}\end{array}$ & 1.00 & & & \\
\hline 15 & Directors paid with equity & $\begin{array}{l}0.00 \\
{[0.52]}\end{array}$ & $\begin{array}{l}0.07 \\
{[0.00]}\end{array}$ & $\begin{array}{l}0.02 \\
{[0.02]}\end{array}$ & $\begin{array}{l}0.06 \\
{[0.00]}\end{array}$ & $\begin{array}{l}-0.01 \\
{[0.29]}\end{array}$ & $\begin{array}{l}0.20 \\
{[0.00]}\end{array}$ & $\begin{array}{l}0.00 \\
{[0.62]}\end{array}$ & $\begin{array}{l}0.00 \\
{[0.78]}\end{array}$ & $\begin{array}{l}0.02 \\
{[0.00]}\end{array}$ & $\begin{array}{l}0.00 \\
{[0.51]}\end{array}$ & $\begin{array}{l}0.03 \\
{[0.00]}\end{array}$ & $\begin{array}{l}0.05 \\
{[0.00]}\end{array}$ & $\begin{array}{l}0.09 \\
{[0.00]}\end{array}$ & $\begin{array}{l}-0.19 \\
{[0.00]}\end{array}$ & 1.00 & & \\
\hline 16 & Fraction of independent female directors & $\begin{array}{l}0.01 \\
{[0.23]}\end{array}$ & $\begin{array}{l}0.91 \\
{[0.00]}\end{array}$ & $\begin{array}{l}0.11 \\
{[0.00]}\end{array}$ & $\begin{array}{l}0.70 \\
{[0.00]}\end{array}$ & $\begin{array}{l}0.24 \\
{[0.00]}\end{array}$ & $\begin{array}{l}0.37 \\
{[0.00]}\end{array}$ & $\begin{array}{l}0.08 \\
{[0.00]}\end{array}$ & $\begin{array}{l}0.00 \\
{[0.91]}\end{array}$ & $\begin{array}{l}-0.03 \\
{[0.00]}\end{array}$ & $\begin{array}{l}0.04 \\
{[0.00]}\end{array}$ & $\begin{array}{l}0.06 \\
{[0.00]}\end{array}$ & $\begin{array}{l}-0.13 \\
{[0.00]}\end{array}$ & $\begin{array}{l}0.28 \\
{[0.00]}\end{array}$ & $\begin{array}{l}-0.20 \\
{[0.00]}\end{array}$ & $\begin{array}{l}0.10 \\
{[0.00]}\end{array}$ & 1.00 & \\
\hline 17 & Fraction of dependent female directors & $\begin{array}{l}-0.02 \\
{[0.01]}\end{array}$ & $\begin{array}{l}0.37 \\
{[0.00]}\end{array}$ & $\begin{array}{l}0.04 \\
{[0.00]}\end{array}$ & $\begin{array}{l}0.23 \\
{[0.00]}\end{array}$ & $\begin{array}{l}0.04 \\
{[0.00]}\end{array}$ & $\begin{array}{l}-0.23 \\
{[0.00]}\end{array}$ & $\begin{array}{l}-0.01 \\
{[0.07]}\end{array}$ & $\begin{array}{l}0.00 \\
{[0.80]}\end{array}$ & $\begin{array}{l}0.02 \\
{[0.03]}\end{array}$ & $\begin{array}{l}0.01 \\
{[0.20]}\end{array}$ & $\begin{array}{l}0.00 \\
{[0.61]}\end{array}$ & $\begin{array}{l}0.01 \\
{[0.32]}\end{array}$ & $\begin{array}{l}0.00 \\
{[0.84]}\end{array}$ & $\begin{array}{l}0.15 \\
{[0.00]}\end{array}$ & $\begin{array}{l}-0.04 \\
{[0.00]}\end{array}$ & $\begin{array}{l}-0.05 \\
{[0.00]}\end{array}$ & 1.00 \\
\hline
\end{tabular}


Panel C: Explaining Bid Initiation

\begin{tabular}{|c|c|c|}
\hline \multirow[t]{2}{*}{ Dependent variable } & \multicolumn{2}{|c|}{ \# M\&A bid initiations } \\
\hline & (1) & (2) \\
\hline Fraction of female directors & $\begin{array}{l}-0.7831 \text { *** } \\
(0.299)\end{array}$ & \\
\hline One female director & & $\begin{array}{l}-0.1213^{* *} \\
(0.058)\end{array}$ \\
\hline Multiple female directors & & $\begin{array}{l}-0.2369^{* * * *} \\
(0.075)\end{array}$ \\
\hline Board size & $\begin{array}{l}-0.0076 \\
(0.010)\end{array}$ & $\begin{array}{l}0.0013 \\
(0.010)\end{array}$ \\
\hline Fraction of independent directors & $\begin{array}{l}-0.1638 \\
(0.145)\end{array}$ & $\begin{array}{l}-0.1405 \\
(0.145)\end{array}$ \\
\hline CEO being COB & $\begin{array}{l}0.0255 \\
(0.047)\end{array}$ & $\begin{array}{l}0.0247 \\
(0.047)\end{array}$ \\
\hline Sales growth & $\begin{array}{l}-0.0019 \\
(0.010)\end{array}$ & $\begin{array}{l}-0.0021 \\
(0.010)\end{array}$ \\
\hline Tobin's Q & $\begin{array}{l}-0.0098 \\
(0.011)\end{array}$ & $\begin{array}{l}-0.0098 \\
(0.011)\end{array}$ \\
\hline ROA & $\begin{array}{l}0.1026 \\
(0.086)\end{array}$ & $\begin{array}{l}0.1042 \\
(0.087)\end{array}$ \\
\hline Book leverage & $\begin{array}{l}-0.2510^{*} \\
(0.142)\end{array}$ & $\begin{array}{l}-0.2491 * \\
(0.142)\end{array}$ \\
\hline Cashholding & $\begin{array}{l}-0.2958^{*} \\
(0.168)\end{array}$ & $\begin{array}{l}-0.2986^{*} \\
(0.169)\end{array}$ \\
\hline Logarithm of market capitalization & $\begin{array}{l}0.3356^{* * *} \\
(0.017)\end{array}$ & $\begin{array}{l}0.3383^{* * *} \\
(0.017)\end{array}$ \\
\hline Constant & $\begin{array}{l}-3.0866^{* * * *} \\
(0.428)\end{array}$ & $\begin{array}{l}-3.1736^{* * * *} \\
(0.431)\end{array}$ \\
\hline Year fixed effects & Yes & Yes \\
\hline Industry fixed effects & Yes & Yes \\
\hline Cluster by firm & Yes & Yes \\
\hline Observations & 19,521 & 19,521 \\
\hline Pseudo R-squared & 0.155 & 0.155 \\
\hline
\end{tabular}


Table 2

Summary Statistics on Bids, Boards, Bidders, and Target Firms, 1997-2009

Our mergers and acquisitions sample consists of 458 deals announced during the period 1997-2009. The data are retrieved from the SDC database and have available information on firm and board characteristics of both bidder and target firms from Compustat/CRSP/RiskMetrics. All firm characteristics are measured at the fiscal year end prior to the bid announcement date. See the Appendix for definition of the variables. All percentages are in decimal format.

\begin{tabular}{|c|c|c|c|c|c|c|}
\hline Variable & $\mathrm{N}$ & Mean & StdDev & $\begin{array}{r}5^{\text {th }} \\
\text { Percentile } \\
\end{array}$ & Median & $\begin{array}{r}95^{\mathrm{tl}} \\
\text { Percentile } \\
\end{array}$ \\
\hline Bid premium & 458 & 0.354 & 0.312 & -0.016 & 0.305 & 0.917 \\
\hline Bidder fraction of female directors & 458 & 0.107 & 0.078 & 0.000 & 0.100 & 0.250 \\
\hline Bidder one female director & 458 & 0.448 & 0.498 & 0.000 & 0.000 & 1.000 \\
\hline Bidder multiple female directors & 458 & 0.338 & 0.474 & 0.000 & 0.000 & 1.000 \\
\hline Target fraction of female directors & 458 & 0.080 & 0.082 & 0.000 & 0.083 & 0.222 \\
\hline Target one female director & 458 & 0.358 & 0.480 & 0.000 & 0.000 & 1.000 \\
\hline Target multiple female directors & 458 & 0.223 & 0.417 & 0.000 & 0.000 & 1.000 \\
\hline Toehold & 458 & 0.006 & 0.037 & 0.000 & 0.000 & 0.000 \\
\hline Allcash & 458 & 0.192 & 0.394 & 0.000 & 0.000 & 1.000 \\
\hline Allstock & 458 & 0.349 & 0.477 & 0.000 & 0.000 & 1.000 \\
\hline Bidder board size & 458 & 11.282 & 3.728 & 7.000 & 11.000 & 18.000 \\
\hline Bidder fraction of independent directors & 458 & 0.675 & 0.184 & 0.286 & 0.704 & 0.909 \\
\hline Bidder CEO being COB & 458 & 0.758 & 0.429 & 0.000 & 1.000 & 1.000 \\
\hline Bidder sales growth & 458 & 0.243 & 0.475 & -0.128 & 0.126 & 0.909 \\
\hline Bidder Tobin's Q & 458 & 2.262 & 1.998 & 1.053 & 1.603 & 5.595 \\
\hline Bidder ROA & 458 & 0.056 & 0.175 & -0.012 & 0.054 & 0.210 \\
\hline Bidder book leverage & 458 & 0.252 & 0.166 & 0.000 & 0.241 & 0.540 \\
\hline Target board size & 458 & 9.762 & 3.243 & 5.000 & 9.000 & 15.000 \\
\hline Target fraction of independent directors & 458 & 0.672 & 0.172 & 0.333 & 0.692 & 0.900 \\
\hline Target CEO being COB & 458 & 0.651 & 0.477 & 0.000 & 1.000 & 1.000 \\
\hline Target sales growth & 458 & 0.148 & 0.350 & -0.189 & 0.101 & 0.668 \\
\hline Target Tobin's Q & 458 & 1.851 & 1.355 & 0.986 & 1.438 & 4.089 \\
\hline Target ROA & 458 & 0.046 & 0.104 & -0.069 & 0.041 & 0.181 \\
\hline Target book leverage & 458 & 0.253 & 0.187 & 0.000 & 0.256 & 0.564 \\
\hline Tender offer & 458 & 0.151 & 0.358 & 0.000 & 0.000 & 1.000 \\
\hline Unfriendly & 458 & 0.109 & 0.312 & 0.000 & 0.000 & 1.000 \\
\hline Relative size & 458 & 0.320 & 0.365 & 0.008 & 0.208 & 1.090 \\
\hline Bidder ownership of directors & 396 & 0.056 & 0.110 & 0.001 & 0.014 & 0.263 \\
\hline Bidder directors paid with equity & 443 & 0.878 & 0.328 & 0.000 & 1.000 & 1.000 \\
\hline Target ownership of directors & 388 & 0.074 & 0.131 & 0.003 & 0.030 & 0.254 \\
\hline Target directors paid with equity & 376 & 0.856 & 0.351 & 0.000 & 1.000 & 1.000 \\
\hline Bidder fraction of independent female directors & 458 & 0.095 & 0.076 & 0.000 & 0.091 & 0.231 \\
\hline Bidder fraction of dependent female directors & 458 & 0.012 & 0.033 & 0.000 & 0.000 & 0.091 \\
\hline Target fraction of independent female directors & 458 & 0.070 & 0.077 & 0.000 & 0.071 & 0.222 \\
\hline Target fraction of dependent female directors & 458 & 0.011 & 0.033 & 0.000 & 0.000 & 0.100 \\
\hline
\end{tabular}




\section{Table 3}

The Correlation Matrix

Our mergers and acquisitions sample consists of 458 deals announced during the period 1997-2009. The data are retrieved from the SDC database and have available information on firm and board characteristics of both bidder and target firms from Compustat/CRSP/RiskMetrics. All firm characteristics are measured at the fiscal year end prior to the bid announcement date. See the Appendix for definition of the variables. All percentages are in decimal format. 


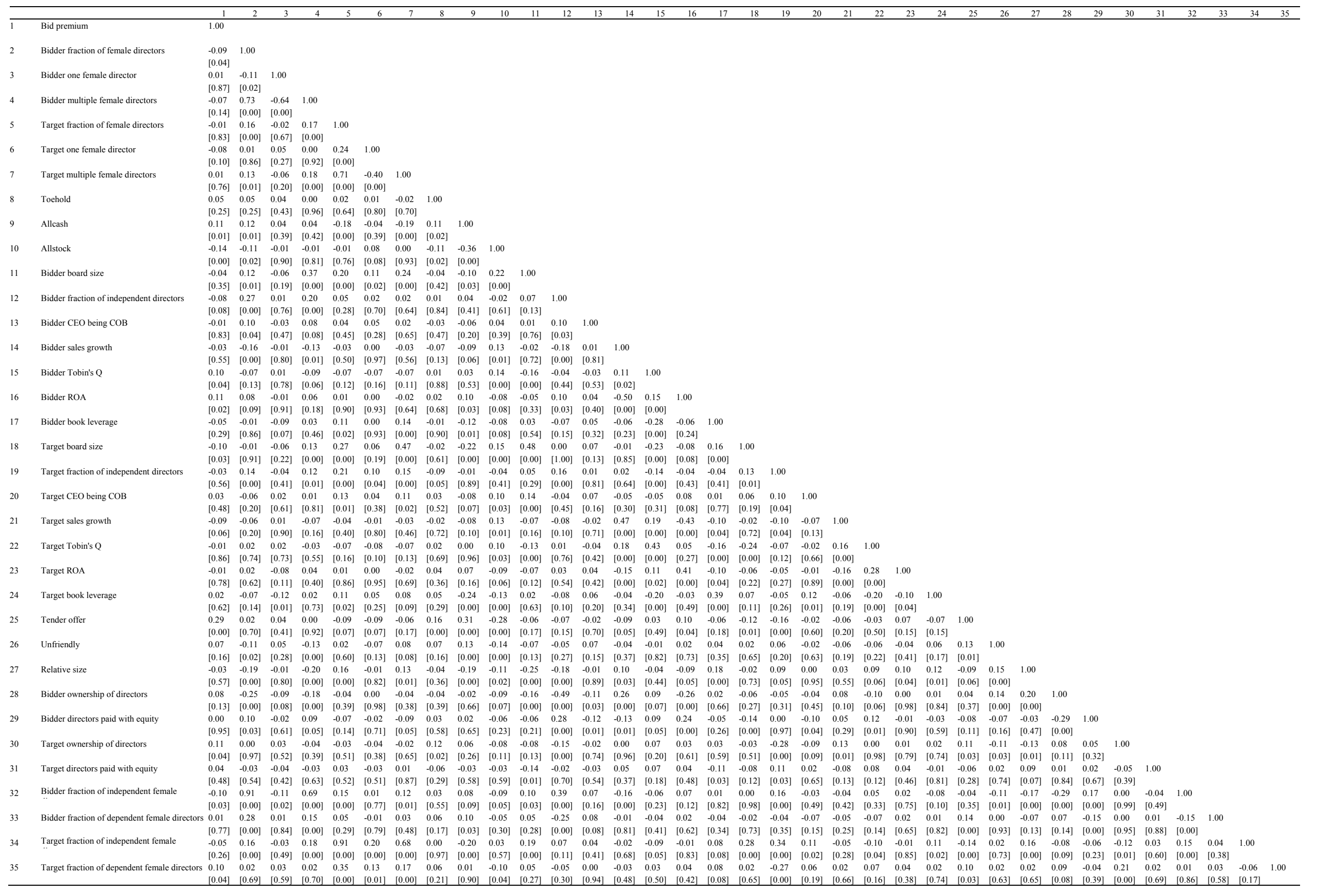


Table 4

Bid Premium

This table reports the OLS regression results for the size of the bid premium. Our mergers and acquisitions sample consists of 458 deals announced during the period 1997-2009. The data are retrieved from the SDC database and have available information on firm and board characteristics of both bidder and target firms from Compustat/CRSP/RiskMetrics. All firm characteristics are measured at the fiscal year end prior to the bid announcement date. See the Appendix for definition of the variables. All percentages are in decimal format. All model specifications employ robust standard errors, which are reported in the parentheses below each coefficient. Superscripts $* * *, * *$, and * correspond to statistical significance at the one, five, and ten percent levels, respectively.

\begin{tabular}{|c|c|c|c|}
\hline \multirow[t]{2}{*}{ Dependent variable } & \multicolumn{3}{|c|}{ Bid premium } \\
\hline & $(1)$ & $(2)$ & (3) \\
\hline Bidder fraction of female directors & $\begin{array}{l}-0.4693^{* *} \\
(0.198)\end{array}$ & $\begin{array}{l}-0.4656^{* *} \\
(0.193)\end{array}$ & \\
\hline Bidder one female director & & & $\begin{array}{l}-0.0801^{* *} \\
(0.037)\end{array}$ \\
\hline Bidder multiple female directors & & & $\begin{array}{l}-0.1154^{* *} \\
(0.046)\end{array}$ \\
\hline Target fraction of female directors & $\begin{array}{l}0.0934 \\
(0.202)\end{array}$ & $\begin{array}{l}0.1183 \\
(0.201)\end{array}$ & \\
\hline Target one female director & & & $\begin{array}{l}-0.0180 \\
(0.033)\end{array}$ \\
\hline Target multiple female directors & & & $\begin{array}{l}0.0633 \\
(0.054)\end{array}$ \\
\hline Toehold & $\begin{array}{l}-0.1229 \\
(0.387)\end{array}$ & $\begin{array}{l}-0.2960 \\
(0.426)\end{array}$ & $\begin{array}{l}-0.2840 \\
(0.426)\end{array}$ \\
\hline Allcash & $\begin{array}{l}0.0783 \\
(0.056)\end{array}$ & $\begin{array}{l}0.0368 \\
(0.052)\end{array}$ & $\begin{array}{l}0.0428 \\
(0.052)\end{array}$ \\
\hline Allstock & $\begin{array}{l}-0.0824^{* *} \\
(0.033)\end{array}$ & $\begin{array}{l}-0.0551 \\
(0.034)\end{array}$ & $\begin{array}{l}-0.0518 \\
(0.034)\end{array}$ \\
\hline Bidder board size & $\begin{array}{l}0.0000 \\
(0.004)\end{array}$ & $\begin{array}{l}-0.0006 \\
(0.004)\end{array}$ & $\begin{array}{l}0.0028 \\
(0.005)\end{array}$ \\
\hline Bidder fraction of independent directors & $\begin{array}{l}0.0303 \\
(0.086)\end{array}$ & $\begin{array}{l}0.0219 \\
(0.087)\end{array}$ & $\begin{array}{l}0.0343 \\
(0.088)\end{array}$ \\
\hline Bidder CEO being COB & $\begin{array}{l}0.0200 \\
(0.031)\end{array}$ & $\begin{array}{l}0.0166 \\
(0.031)\end{array}$ & $\begin{array}{l}0.0159 \\
(0.032)\end{array}$ \\
\hline Bidder sales growth & $\begin{array}{l}0.0283 \\
(0.036)\end{array}$ & $\begin{array}{l}0.0310 \\
(0.035)\end{array}$ & $\begin{array}{l}0.0299 \\
(0.035)\end{array}$ \\
\hline Bidder Tobin's Q & $\begin{array}{l}0.0046 \\
(0.008)\end{array}$ & $\begin{array}{l}0.0058 \\
(0.007)\end{array}$ & $\begin{array}{l}0.0046 \\
(0.007)\end{array}$ \\
\hline Bidder ROA & $\begin{array}{l}0.1788^{* *} \\
(0.089)\end{array}$ & $\begin{array}{l}0.1537^{*} \\
(0.089)\end{array}$ & $\begin{array}{l}0.1608^{*} \\
(0.087)\end{array}$ \\
\hline Bidder book leverage & $\begin{array}{l}-0.0981 \\
(0.099)\end{array}$ & $\begin{array}{l}-0.0766 \\
(0.098)\end{array}$ & $\begin{array}{l}-0.0939 \\
(0.098)\end{array}$ \\
\hline Target board size & $\begin{array}{l}-0.0073 \\
(0.005)\end{array}$ & $\begin{array}{l}-0.0066 \\
(0.005)\end{array}$ & $\begin{array}{l}-0.0099 * \\
(0.006)\end{array}$ \\
\hline Target fraction of independent directors & $\begin{array}{l}0.0693 \\
(0.091)\end{array}$ & $\begin{array}{l}0.1042 \\
(0.090)\end{array}$ & $\begin{array}{l}0.1110 \\
(0.090)\end{array}$ \\
\hline Target CEO being COB & $\begin{array}{l}0.0080 \\
(0.030)\end{array}$ & $\begin{array}{l}0.0083 \\
(0.029)\end{array}$ & $\begin{array}{l}0.0087 \\
(0.028)\end{array}$ \\
\hline
\end{tabular}




\begin{tabular}{llll} 
Target sales growth & -0.0626 & -0.0643 & -0.0618 \\
Target Tobin's Q & $(0.047)$ & $(0.045)$ & $(0.044)$ \\
& 0.0020 & 0.0067 & 0.0053 \\
Target ROA & $(0.013)$ & $(0.013)$ & $(0.013)$ \\
& -0.2889 & -0.2816 & -0.2839 \\
Target book leverage & $(0.198)$ & $(0.189)$ & $(0.187)$ \\
& 0.0304 & 0.0627 & 0.0587 \\
Tender offer & $(0.107)$ & $(0.110)$ & $(0.113)$ \\
& & $0.1809^{* * * *}$ & $0.1788^{* * *}$ \\
Unfriendly & & $(0.058)$ & $(0.058)$ \\
& & 0.0195 & 0.0119 \\
Relative size & & $(0.040)$ & $(0.041)$ \\
& & -0.0244 & -0.0286 \\
Constant & & $(0.039)$ & $(0.039)$ \\
& $0.5124^{* * *}$ & $0.4996^{* * *}$ & $0.5254^{* * *}$ \\
Year fixed effects & $(0.122)$ & $(0.121)$ & $(0.120)$ \\
Industry fixed effects & & & \\
Observations & Yes & Yes & Yes \\
Adjusted R-squared & Yes & Yes & Yes \\
\hline
\end{tabular}




\section{Table 5}

\section{Robustness Checks}

This table presents robustness checks on our main results. All firm characteristics are measured at the fiscal year end prior to the bid announcement date. See the Appendix for definition of the variables. All percentages are in decimal format. Panel A reports the Negative Binomial regression results for the number of bid initiations; Panel B reports the OLS regression results for the size of the bid premium. In Columns (1) and (2) of Panels A and B, we control for director ownership and director compensation. In Column (3) of Panels A and B, we decompose female directors into two categories: independent versus dependent ones. Our bid initiation samples in Columns (1)-(2) and Column (3) of Panel A consist of 16,489 and 19,521 firm-year observations during the period 1997-2009, respectively. Our mergers and acquisitions samples in Columns (1)-(2) and Column (3) of Panel B consist of 315 and 458 deals announced during the period 1997-2009, respectively. All model specifications employ robust standard errors. The standard errors in Panel A are also clustered by firm. The corresponding standard error is reported in the parentheses below each coefficient. Superscripts ***,**, and * correspond to statistical significance at the one, five, and ten percent levels, respectively. 


\begin{tabular}{|c|c|c|c|}
\hline \multirow[t]{2}{*}{ Dependent variable } & \multicolumn{3}{|c|}{ \# M\&A bid initiations } \\
\hline & $(1)$ & $(2)$ & $(3)$ \\
\hline Fraction of female directors & $\begin{array}{l}-0.7274 * * \\
(0.313)\end{array}$ & & \\
\hline One female director & & $\begin{array}{l}-0.1242^{*} \\
(0.064)\end{array}$ & \\
\hline Multiple female directors & & $\begin{array}{l}-0.2303 * * * \\
(0.081)\end{array}$ & \\
\hline Fraction of independent female directors & & & $\begin{array}{l}-0.6507^{* *} \\
(0.303)\end{array}$ \\
\hline Fraction of dependent female directors & & & $\begin{array}{l}-1.3854^{*} \\
(0.759)\end{array}$ \\
\hline Board size & $\begin{array}{l}-0.0136 \\
(0.011)\end{array}$ & $\begin{array}{l}-0.0046 \\
(0.012)\end{array}$ & $\begin{array}{l}-0.0076 \\
(0.010)\end{array}$ \\
\hline Fraction of independent directors & $\begin{array}{l}-0.3585^{* *} \\
(0.173)\end{array}$ & $\begin{array}{l}-0.3331 * \\
(0.173)\end{array}$ & $\begin{array}{l}-0.2108 \\
(0.150)\end{array}$ \\
\hline CEO being $\mathrm{COB}$ & $\begin{array}{l}0.0124 \\
(0.050)\end{array}$ & $\begin{array}{l}0.0119 \\
(0.050)\end{array}$ & $\begin{array}{l}0.0256 \\
(0.047)\end{array}$ \\
\hline Sales growth & $\begin{array}{l}-0.0128 \\
(0.014)\end{array}$ & $\begin{array}{l}-0.0131 \\
(0.014)\end{array}$ & $\begin{array}{l}-0.0021 \\
(0.010)\end{array}$ \\
\hline Tobin's Q & $\begin{array}{l}-0.0106 \\
(0.012)\end{array}$ & $\begin{array}{l}-0.0106 \\
(0.012)\end{array}$ & $\begin{array}{l}-0.0098 \\
(0.011)\end{array}$ \\
\hline ROA & $\begin{array}{l}0.2369 \\
(0.184)\end{array}$ & $\begin{array}{l}0.2416 \\
(0.187)\end{array}$ & $\begin{array}{l}0.1041 \\
(0.086)\end{array}$ \\
\hline Book leverage & $\begin{array}{l}-0.2627 \\
(0.163)\end{array}$ & $\begin{array}{l}-0.2612 \\
(0.163)\end{array}$ & $\begin{array}{l}-0.2521 * \\
(0.142)\end{array}$ \\
\hline Cashholding & $\begin{array}{l}-0.3075^{*} \\
(0.175)\end{array}$ & $\begin{array}{l}-0.3103^{*} \\
(0.176)\end{array}$ & $\begin{array}{l}-0.2871^{*} \\
(0.167)\end{array}$ \\
\hline Logarithm of market capitalization & $\begin{array}{l}0.3258^{* * * *} \\
(0.018)\end{array}$ & $\begin{array}{l}0.3285^{* * *} \\
(0.018)\end{array}$ & $\begin{array}{l}0.3341^{* * *} \\
(0.017)\end{array}$ \\
\hline Ownership of directors & $\begin{array}{l}-0.4785^{* *} \\
(0.244)\end{array}$ & $\begin{array}{l}-0.4831^{* *} \\
(0.244)\end{array}$ & \\
\hline Directors paid with equity & $\begin{array}{l}-0.0078 \\
(0.088)\end{array}$ & $\begin{array}{l}-0.0045 \\
(0.088)\end{array}$ & \\
\hline Constant & $\begin{array}{l}-6.4341^{* * *} \\
(0.646)\end{array}$ & $\begin{array}{l}-6.5195^{* * * *} \\
(0.650)\end{array}$ & $\begin{array}{l}-3.0530^{* * *} \\
(0.427)\end{array}$ \\
\hline Year fixed effects & Yes & Yes & Yes \\
\hline Industry fixed effects & Yes & Yes & Yes \\
\hline Cluster by firm & Yes & Yes & Yes \\
\hline Observations & 16,489 & 16,489 & 19,521 \\
\hline Pseudo R-squared & 0.155 & 0.155 & 0.155 \\
\hline
\end{tabular}


Panel B: Robustness Checks for Bid Premium

\begin{tabular}{|c|c|c|c|}
\hline Dependent variable & & Bid premium & \\
\hline & $(1)$ & $(2)$ & (3) \\
\hline Bidder fraction of female directors & $\begin{array}{l}-0.5818^{* * *} \\
(0.220)\end{array}$ & & \\
\hline Bidder one female director & & $\begin{array}{l}-0.1307^{* * *} \\
(0.050)\end{array}$ & \\
\hline Bidder multiple female directors & & $\begin{array}{l}-0.1781 * * * \\
(0.059)\end{array}$ & \\
\hline Bidder fraction of independent female directors & & & $\begin{array}{l}-0.3910^{* *} \\
(0.196)\end{array}$ \\
\hline Bidder fraction of dependent female directors & & & $\begin{array}{l}-0.8541^{*} \\
(0.489)\end{array}$ \\
\hline Target fraction of female directors & $\begin{array}{l}-0.0850 \\
(0.238)\end{array}$ & & \\
\hline Target one female director & & $\begin{array}{l}-0.0402 \\
(0.042)\end{array}$ & \\
\hline Target multiple female directors & & $\begin{array}{l}0.0435 \\
(0.070)\end{array}$ & \\
\hline Target fraction of independent female directors & & & $\begin{array}{l}0.0012 \\
(0.191)\end{array}$ \\
\hline Target fraction of dependent female directors & & & $\begin{array}{l}0.7070 \\
(0.565)\end{array}$ \\
\hline Toehold & $\begin{array}{l}-0.0819 \\
(0.508)\end{array}$ & $\begin{array}{l}-0.0542 \\
(0.478)\end{array}$ & $\begin{array}{l}-0.2878 \\
(0.426)\end{array}$ \\
\hline Allcash & $\begin{array}{l}0.0552 \\
(0.067)\end{array}$ & $\begin{array}{l}0.0739 \\
(0.071)\end{array}$ & $\begin{array}{l}0.0392 \\
(0.052)\end{array}$ \\
\hline Allstock & $\begin{array}{l}-0.0498 \\
(0.041)\end{array}$ & $\begin{array}{l}-0.0456 \\
(0.042)\end{array}$ & $\begin{array}{l}-0.0485 \\
(0.036)\end{array}$ \\
\hline Bidder board size & $\begin{array}{l}0.0042 \\
(0.006)\end{array}$ & $\begin{array}{l}0.0096 \\
(0.006)\end{array}$ & $\begin{array}{l}-0.0007 \\
(0.004)\end{array}$ \\
\hline Bidder fraction of independent directors & $\begin{array}{l}-0.0244 \\
(0.137)\end{array}$ & $\begin{array}{l}-0.0084 \\
(0.140)\end{array}$ & $\begin{array}{l}-0.0050 \\
(0.090)\end{array}$ \\
\hline Bidder CEO being COB & $\begin{array}{l}0.0119 \\
(0.038)\end{array}$ & $\begin{array}{l}0.0146 \\
(0.038)\end{array}$ & $\begin{array}{l}0.0197 \\
(0.032)\end{array}$ \\
\hline Bidder sales growth & $\begin{array}{l}0.0346 \\
(0.043)\end{array}$ & $\begin{array}{l}0.0303 \\
(0.042)\end{array}$ & $\begin{array}{l}0.0315 \\
(0.035)\end{array}$ \\
\hline Bidder Tobin's Q & $\begin{array}{l}0.0121 \\
(0.008)\end{array}$ & $\begin{array}{l}0.0098 \\
(0.008)\end{array}$ & $\begin{array}{l}0.0057 \\
(0.008)\end{array}$ \\
\hline Bidder ROA & $\begin{array}{l}0.0640 \\
(0.117)\end{array}$ & $\begin{array}{l}0.0849 \\
(0.119)\end{array}$ & $\begin{array}{l}0.1528^{*} \\
(0.088)\end{array}$ \\
\hline Bidder book leverage & $\begin{array}{l}-0.0316 \\
(0.115)\end{array}$ & $\begin{array}{l}-0.0436 \\
(0.113)\end{array}$ & $\begin{array}{l}-0.0940 \\
(0.100)\end{array}$ \\
\hline Target board size & $\begin{array}{l}-0.0164^{* *} \\
(0.007)\end{array}$ & $\begin{array}{l}-0.0209^{* *} \\
(0.008)\end{array}$ & $\begin{array}{l}-0.0066 \\
(0.005)\end{array}$ \\
\hline Target fraction of independent directors & $\begin{array}{l}0.1399 \\
(0.114)\end{array}$ & $\begin{array}{l}0.1377 \\
(0.113)\end{array}$ & $\begin{array}{l}0.1507 \\
(0.094)\end{array}$ \\
\hline Target CEO being COB & $\begin{array}{l}0.0123 \\
(0.037)\end{array}$ & $\begin{array}{l}0.0102 \\
(0.036)\end{array}$ & $\begin{array}{l}0.0036 \\
(0.028)\end{array}$ \\
\hline Target sales growth & -0.0575 & -0.0492 & -0.0670 \\
\hline
\end{tabular}




\begin{tabular}{llll} 
Target Tobin's Q & 0.0066 & 0.0051 & 0.0047 \\
Target ROA & $(0.013)$ & $(0.013)$ & $(0.013)$ \\
& -0.3956 & -0.3971 & -0.2707 \\
Target book leverage & $(0.248)$ & $(0.244)$ & $(0.191)$ \\
& 0.1585 & 0.1470 & 0.0755 \\
Tender offer & $(0.150)$ & $(0.153)$ & $(0.113)$ \\
& $0.2416^{* * *}$ & $0.2481^{* * *}$ & $0.1818^{* * *}$ \\
Unfriendly & $(0.080)$ & $(0.081)$ & $(0.059)$ \\
& -0.0002 & -0.0154 & 0.0174 \\
Relative size & $(0.046)$ & $(0.051)$ & $(0.039)$ \\
& -0.0479 & -0.0600 & -0.0229 \\
Bidder ownership of directors & $(0.052)$ & $(0.050)$ & $(0.038)$ \\
& 0.0073 & 0.0021 & \\
Bidder directors paid with equity & $(0.172)$ & $(0.178)$ & \\
Target ownership of directors & 0.0411 & 0.0530 & \\
& $(0.066)$ & $(0.065)$ & \\
Target directors paid with equity & 0.0952 & 0.0347 & \\
& $(0.169)$ & $(0.160)$ & \\
Constant & 0.0487 & 0.0478 & \\
& $(0.045)$ & $(0.045)$ & \\
Year fixed effects & 0.1005 & 0.1238 & $0.4853^{* * *}$ \\
Industry fixed effects & $(0.206)$ & $(0.207)$ & $(0.127)$ \\
Observations & & & \\
Adjusted R-squared & Yes & Yes & Yes \\
& Yes & Yes & Yes \\
& 315 & 315 & 458 \\
& 0.18 & 0.18 & 0.16 \\
\hline & & & \\
& & & \\
& & &
\end{tabular}

